\title{
Investigating the Structural Gap in Igbo Dance Theatre through the Primary, Performative and Quoting Repertoire Theories
}

\author{
Christian Ikechukwu Nwaru \\ Department of Theatre and Performance, School of the Arts, University of Northampton, Northamptonshire, United Kingdom
}

\section{Email address:}

chrisnwaru@yahoo.com

\section{To cite this article:}

Christian Ikechukwu Nwaru. Investigating the Structural Gap in Igbo Dance Theatre through the Primary, Performative and Quoting Repertoire Theories. Humanities and Social Sciences. Vol. 3, No. 5, 2015, pp. 201-206. doi: 10.11648/j.hss.20150305.16

\begin{abstract}
This work represents an on-going Ph.D. investigation of Igbo dance theatre in eastern Nigeria. Existing research on Igbo dance theatre reveals that different authors wrote about the forms of Igbo dance theatre and called them 'Igbo dance theatre'. Furthermore, some scholars have also shown and commented on dance forms such as Okunmkpo, Odo and Ekpe as Igbo dance theatre. The concept of Igbo dance theatre as used in this study differs from those presentations and forms characterised by incomplete structures and plots that do not best describe Igbo dance theatre. In some forms of Igbo contemporary dance theatre, what audiences and participants witness is merely one stage of a spectrum whose other sections are neither visible nor necessarily articulated in and through dance. Thus, what is on show in many Igbo dances is only a part of the whole and it takes the combination of the visible stage action and an understanding of the imagined contents of missing sections, the latter being generally inferred or derived from legends, myths, folktales and from social commentary, for audiences to appreciate the full meaning and significance of Igbo dance theatre. This research is based on the premise that the structure of Igbo dance forms discussed earlier are sequestered, creating a 'missing link.' This case study provides an account of some practical aspects of an on-going Ph.D. project that focuses and draws upon primary research, Brad Haseman's performative research theory and Yvonne Hardt's repertoire theory. Performative research theory is concerned with those researchers who carry out practice-led research and such research is intrinsically experiential and comes to the fore when the researcher creates new artistic forms. Repertoire theory demonstrates how artists discover and use materials from the past to formulate new constructs based on the needs of present dance performances. Given that the primary goal of this investigation is to re-create and re-interpret Igbo dance form as a full dance theatre, where the narrative is not assumed to be clearly understood by the audience, both paradigms are useful for explaining the cultural histories, abstract symbols and information, the missing links and working structure of Igbo dance theatre.
\end{abstract}

Keywords: Investigating, Structural Gap, Igbo Dance Theatre, Primary, Performative, Quoting Repertoire Theories

\section{Project Overview and Context: Igbo Dance Theatre}

In comparison to other performance arts, Igbo dance is still an under-researched field. This research investigates the form, content and creative processes of Igbo dance theatre in Eastern Nigeria. The study analyses the relationship between dance form (movement and patterns) and content (meanings; story line (where relevant), music, dramatic action, spectacle, plot development, props, costume and make-up). It seeks to explain the generation and communication of information in
Igbo dance theatre by experimenting on the traditional movements, patterns and associated theatrical elements in the form.

Form and Content in dance manifest in the creation and arrangement of dance performance and the effect this has on the audience. Form basically is the variety of a thing, the arrangement of parts in the whole especially (in this case), in a work of art and the final shape it takes. In choreography, Myron Nadal (1978) states that form entails the placement of the parts of a dance into some order, some planned relationship which can be repeatable. This suggests that form in dance is the manner of presentation characteristic of the 
period. It is influenced by fashion and characteristic of different historical periods, societies and individual ideologies of the time (the time during which dance proceeds). This had led to categories and stylistic trait of work of arts in general and dances in particular. The artist of age wants to be recognised as having made an impact to that age. In Julius Portnoy's (1978) opinion such artist strives for immortal recognition by creating something that will live after him. Therefore each cultural phase produces new form. From the study of Igbo dance theatre, it is observable that there are old (traditional) and new (contemporary) forms of dance. Ahmed Yerima (2006) opines that traditional dance is classified as dances that exist in sacred religious practice, soaked in ritual and legend and preserved by folklores. The traditional dance is largely engaged in spiritual activities and social content tied to the world view of the society. Rasaki Ojo Bakare (2006) is of the view that contemporary dance compositions are devised to express creative freedom and artistic individuality. These are the two major forms to be considered in this study. The different genres of choreography (traditional and contemporary) could be found among the Igbos in Nigeria.

\section{Research Practicalities}

This is an on-going Ph.D. research project with the School of the Arts, University of Northampton in the UK. I enrolled my Ph.D. programme in May, 2012. In the University of Northampton Ph.D. mile-stone, I am heading for the writing up stage. I conducted my field research from 4th January to 12th March, 2013. In the field, interviews and observations were conducted in Nigeria. Unstructured interviews were conducted with dance teachers, community chieftains and leaders, village heads, professionals and amateur practitioners. Observation and participant observation were carried on some dance theatres. The studio practice research took place at the Theatre Complex, Alvan Ikoku Federal College of Education, Owerri, Imo State, Nigeria from 15th March to 25th April, 2013.

\section{Methods in Action}

Researchers/choreographers engage with different methodologies and theories in explaining or analysing their work. The questions of the research titled "Contextualizing Form, Content \& Creative Practice in Igbo Dance Theatre" are specific:

- How does contemporary Igbo dance theatre differ in structure, form and content from its archetypal models that were based on rituals and sociocultural practises?

- How does the absence of exposition and post-climactic stages in contemporary Igbo dance theatre provide space for new creative energies and new dance practices?

The process of creating a dramatic Igbo dance theatre in the dance studio and its creative outcome were based on the data collected from field-work. The purpose for the field- work was to generate information on dance narratives, patterns, design and overall aesthetic strategies, to identify differences between selected contemporary dances and their archetypes, to guide the creative practice and the integration of features of archetypal and modern dance forms into a dramatic dance theatre, as well as explore the extents to which the exposition and post-climatic stages in archetypes (missing links in contemporary forms) provide material and context for a different kind of Igbo dance theatre. Some of the information in this research was generated from workshops, seminars and conferences. Library search on journals and books have highlighted the gaps in the study of Igbo dance theatre and helped in framing the theoretical definitions of key words in this study such as (dance theatre, forms, contents, creative practice).

\section{Primary Research}

For a thorough investigation of the sequestered stages in Igbo dance theatre, there is the need to engage in primary research, in this case, field work. According to Dana Lynn Driscoll (2011), primary research is essential for the collection of data from the field for the purpose of a given research rather than using reported information from books, database, or journal. The suitability of field research as a revealing process for researchers and Bakare (2006) suggestion that choreographers should use the materials from a society's or individual's cultural background to generate and establish "linguistic property" to express his purely creative thoughts' have guided me in devising a 'roadmap' for creative practice in the studio. Earl Babbie (2003) argues that primary research is particularly useful when researchers want to learn about a problem that does not have a wealth of published information. This may be because the problem is a recent event or something not commonly studied. Dance theatre in eastern Nigeria is one of the many subjects that have not been subjected to a lot of critical enquiry. The needs to understand the links, if any between contemporary dances and their archetypes, to document and preserve historical and cultural knowledge in the form of a notation system, and the emphasis on form, context, and creative process of indigenous Igbo dances in a field of study that is still suffering from a dearth of professional expertise and resources are also reasons for the choice of primary research. Driscoll (2011) concludes that the ultimate goal in conducting primary research is to learn about something new that can be confirmed by others and to eliminate our own biases in the process. The primary research paradigms used in this study are interview and observation. The research fieldwork was conducted in four States of Nigeria; Abia, Ebonyi, Anambra and Imo States. The selected States represent the majority of the Igbo regions and will generate information and results that can be applied to all Igbo society.

\subsection{Interview}

According to Driscoll (2011), interviewing involves asking participants questions in a one-on-one or small group setting. 
Steinar Kvale (1996) argues that the qualitative research interview seeks to describe or elucidate the meanings of central themes in the subjects. By this therefore, one can infer that, the main task in interviewing is to understand the meaning of what the interviewees say. Semi-structured interviews were used for this research. Unlike the structured interview in which researchers pose all interviewees exactly the same context of questioning, in semi-structured interview, the order of the questions can be changed depending on the direction of the interview. An interview guide is also used, but additional questions can be asked. The knowledge about archetypes, forms, contents, and creative practices in Igbo dance theatre was sought through such interviews. Semistructured and open-ended interviews were conducted with dance teachers, arts professionals, traditional rulers, village elders and title-holders, amateur and professional dance practitioners. In principle and practice interviewees were able to discuss their perceptions and interpretations with regards to given situations on which they expressed their points of view without interference from researcher and participants. Louis Cohen et el (2000). point out that in research contexts, "... the interview is not simply concerned with collecting data about life; it is part of life itself, its human embeddedness is inescapable". People were interviewed specifically on the origins and histories of selected dances such as Iri-Agha, Agborogu, Nkwa-Umuagbogho, and Nkwa$A g u$ in order to obtain information on the structures, styles, forms, contents and creative processes of the archetypes and contemporary forms of the stated dances. The interviewees' responses are important as they reveal the cultural histories and the ritual and social lives of the communities that own the different dances. There are many important reasons why interviews are effective and important for collecting data and for using it as a research instrument. David Gray (2004) has given the following reasons:

- There is a need to attain highly personalized data; there are opportunities required for probing.

- Respondents are not fluent in the native language of the country, or where they have difficulties with written language.

- The interviewer has the objectives of the research in mind and what issues to cover during the interview.

- The interviewee is allowed to talk freely about the subject.

- The interviewer's role is to check on unclear points and to rephrase the answer to check for accuracy and understanding.

The interviews were helpful in tracing the cultural activities and backgrounds of communities and sub-groups of the Igbo (Ohafia, Afikpo, Ajali and Mbaise) about which little or nothing has been written and published and from which the above named dances have evolved. Interviews also produced important insights into what people thought about the nature and usefulness of a potentially fully developed dramatic dance form in which the cultural background and meanings of aesthetic images are more evident than they have been in the past. In conducting interviews, ethical issues are one of the main concerns. Confidentiality of the interviewees was given and respondents were not affected in any way by the research.

Some of the research questions are;

- Does the dance have an entry or exit? How are these organised? Do they add value to the dance?

- Does the dance communicate or fail to communicate a particular message? Why and how does it communicate or fail to communicate?

- Are movements creative or cultural? How do the movements reflect the cultural lives of the people?

- What are the impacts of folktales, legends, myths, gestures, props to the dance?

- Does the selected dance have a specific theme that it sets out to develop and achieve?

The questions in the interview were open-ended, so as to derive more information. The materials derived from the field through these questions helped me to answer the research questions based on the studio work.

However, interviews have their own limitation as William Foddy (1993) argues that verbal reports are limited to expressions of attitudes, feelings, and opinions rather than to factual accounts of past behaviour and interactions. This challenge was met with field notes and follow-up interviews and discussions designed to distinguish feelings and prejudices from cultural and historical facts and authentic information. In view of the above reasons, it was essential that interviews were combined with researcher observations and records in the forms of field notes, photographs and video images and recordings. Nick Fox (1998) argues that observational studies allow the researcher to see for him/herself what happens, rather than depending on interview and questionnaire respondents.

\subsection{Observations}

David Ngo (2010) defines observation as a method in which a researcher observes and records behaviour, events, activities, tasks and duties while something is happening. Observation has to do with observing and measuring the world around you, including observations of people and other measurable events. The observation of Iri-Agha, NkwaUmuagbogho, Agborogu and Nkwa-Agu dance performances generated first-hand information on dance archetypes and the cultural background and abstracted meaning of contemporary Igbo dance theatre. This also helped to provide a better description of dance as a cultural feature of Igbo society. In preparation, letters were sent to palaces of community chieftains and leaders, cultural troupes, professional and amateur dancers, seeking their consent and participation in the research. Consent approval was necessary, not only for ethical consideration but because the levels participants involved required follow-up contact to verify important information that were not always obvious during interviews and because of the researcher's involvement in the investigation. Fox (1998) is of the opinion that observation is more than just recording of data from the environment. When we observe, we are active, not passive collectors of data like 
a tape recorder or video camera. Our brains are engaged as well as our eyes and ears, organising data so we can make sense of them. Perception is thus part of all human observation. Patrick Holly (2010) argues that qualitative observational research involves more than simply going out into the field and observing a given group or culture. It involves selecting a research setting, gaining access, presenting oneself and gathering. The current forms, structures, contexts and aesthetics of the dances under investigation were carefully documented as Holly (2002) opines that it is helpful in observation methods to use recording devices to take down large amounts of information such as videography, tape recorder and notebook. The advantages of observation method include;

- First-hand information

- They are simple to use

- Data from them can be verified or authenticated from other sources.

Photographs were taken during interviews and observations in the field, video-recordings were made of interviews, meetings with dancers, and rehearsal processes in the studio.

\section{Studio Practice Research}

The studio practice was based on the need to transform field notes and information into performance materials such as narrative, dramatic structure, plot, and movements, for the generation of theatrical atmosphere as well as for identifying potential links between archetypes and the contemporary versions. Studio practice helped in answering the research question; how does the absence of exposition and postclimactic stages in contemporary Igbo dance theatre provide space for new creative energies and new dance practices? Though the research questions were answered in the studio, the material derived through interviews and observations helped to guide the researcher and were used to explore materials and ideas on how to interpret existing-sequestered stages in Igbo dance theatre as well as to create contents for the missing stages leading to a more elaborate dramatic exposition and resolution using materials based on and derived from cultural information. Linda Candy (2006) opines that in practice-based research, one of the bases of its contribution to knowledge is the creative process and its outcome. In terms of how to assess the effectiveness of practice / practice-based as research methodology, its nature, format and outcome in a study such as this one into the form, contents and creative practices in Igbo dance theatre, Christopher Frayling (1997) suggests that the practice based doctorate advances knowledge partly by means of practice. An original/creative piece of work is included in the submission for examination. It is distinct in that significant aspects of the claim for doctoral characteristics of originality, mastery and contribution to the field are held to be demonstrated through the original creative work. Here, Frayling (1997) sets out clearly, that the submitted creative work must be judged by the same criteria as the written text.
Kim Vincs (2010) observes that dance practice has only recently begun to be articulated as a specific methodology for dance research. The idea that writing and dancing together define dance research has been embedded in the field for some time. Vincs' (2010) observation is a longstanding tradition in postgraduate dance education in which performance work is presented and accompanied by a written thesis. A minor thesis typically describes documents and articulates the philosophy of the student's artwork. The attempts to clarify the methodological foundation of this theory are evident in.

\section{Performative Research Theory}

Brad Haseman's (2006) performative research theory was used in this research. It is concerned with those researchers who carry out practice-led research. Practice-led research is intrinsically experiential and comes to the fore when the researcher creates new artistic forms. The 'practice' in 'practice-led research' is primary - it is not an optional extra; it is the necessary pre-condition of engagement in performative research. Performative research represents a move which holds that practice is the principal research activity - rather than only the practice of performance - and sees the material outcomes of practice as all-important representations of research findings in their own right. The principal distinction between this third category and the qualitative and quantitative categories is found in the way it chooses to express its findings. In this case, while findings are expressed in non-numeric data, they can be presented as symbolic forms other than in the words of discursive text. Instead research reporting in this paradigm occurs as rich, presentational forms. The attempt to answer the research question, 'how does the absence of exposition and postclimactic stages in Igbo contemporary dance theatre provide space for new creative energies and new dance practices?' started with practice in form of improvisation in dance. Improvisation is a conversation that begins with thinking, not thought. Because thinking is distinct from thought, this implies a finished product. Key definitions of improvisation were used in this investigation. In dance, Shelly Stone (2007) opines that dance improvisation is movement that is not choreographed ahead of time. It may be structured, guided or free. Brian Magerko and Mark Reidl (2008) are of the opinion that improvisation is a constant process of receiving new inputs and producing new outputs. An improvisational model must be able to process and interpret these inputs as knowledge involved in the decision-making process.

In this research, improvisation and fixed performance were used. Improvisation facilitated experimentation with movement ideas. Only movements with clearly discernible cultural meanings and that are relevant to the aesthetic ideas in the dance and movements with the potential for further development were selected movements created during improvisation and those in archetypal and contemporary repertoires of Igbo dance movements were used to create contents and performance materials. These were re-fined and 
'quoted' in the studio-based dance theatre to generate meaning and communicate to the audience, which is the second aim of this study.

\section{Quoting the Repertoire Theory}

Another theory used in this investigation is 'Quoting the repertoire'. Quoting the repertoire is one of the performance theories of Yvonne Hardt (2012) in a recent book titled New German Dance Studies. This theory deals with engagement with the past (history) in dance studies. The theory demonstrates how artists discover and use materials from the past to formulate new constructs based on the needs of new dance performances. Hardt (2012) traces how contemporary dance performances and historical writings challenge chronological distinctions and the separation of historical periods, the trend is instead, to evoke the past in contemporary dance. She observes that numerous artists and festivals increasingly feature works that address the past having discovered the potential for self-reflexivity in dance in conversation with its history. Based on the concept of history as a construction Hardts (2012) observes that as choreographers work with quotations, historical references and reconstruction, these devices are simultaneously reflected in their citational use and re-contextualisation. 'Quoting', though a linguistic term is in this regard used to describe choreographic strategies of dances. Conventionally, quoting refers to the literal repetition of text or visual elements that make reference to a distinct author. In performance, dancers quote by physically incorporating and experiencing the past. Diana Taylor (2003) suggests that 'quoting' the repertoire challenges conventional means of storing the past. For her, repertoire enacts embodied memory: performance gestures, orality, movements, dance, singing in short, all those acts usually thought of as ephemeral knowledge. According to Hardt (2012), the term 'repertoire', which is also present and used for referring to and rendering historical, mythological and sociocultural information in Igbo dance, signifies that which has made it into the cannon, that which is institutionalized and has been granted the possibility to continue living on stage or to be perpetuated in dance classes. In Igbo society, information can be communicated literally but mostly symbolically. The information communicated can be anything from cultural practices and social conventions to folk beliefs, abstracted legends, myths, and historical events. These cultural materials may be common knowledge but they are not evident in Igbo dance, many of them are imagined as a given, requiring neither showing nor elaboration. Their absence in dance performances creates an imaginary space for audiences to fill in the missing information or narrative from a repertoire of communal knowledge. Thus, though Igbo dance theatre generates meaning by "quoting" aspects of archetypes and traditional repertoires, structurally, contextually and textually, these quotes through dance movements will help to explain cultural histories, abstract symbols and information, and working structure of Igbo dance theatre.

\section{Participation and Selection of Participants}

The research participants are made up of volunteers from local troupes ranging in grades from amateur to experienced artists. The inclusion of a broad spectrum of troupes, individuals and experience levels produced a mixed pool of participants from which to audition and select artists that fit into the study in terms of the selection of communities across all sections of Igbo society, diverse dance styles, and several cultural habits. In total there were over 30 participants, made up of drummers, dancers and a crew that have at least some experience of theatrical dance. In the studio, the following elements of practice were employed as creative research materials: traditional and contemporary Igbo dance steps and movements; designs and floor patterns; vocal and instrumental music; traditional props and costumes. Runthrough, dress and technical rehearsal were all recorded in video-tapes and still photographs. Haseman (2006) argues that in performance research alongside quantitative (symbolic numbers) and qualitative (symbolic words), the symbolic data works performatively. It not only expresses the research, but in that expression is the research itself. The practical outcome of studio research was a public performance. In addition, a written component, electronic materials and evidences from studio practice will be submitted for evaluation.

\section{Conclusion}

The significance of this paper lies in its application of the primary research methods such as interview and observation, Brad Haseman (2006) performative research theory and Yvonne Hardt's (2012) quoting repertoire theory in the creation of the expository and post-climactic stages in Igbo dance theatre as spaces for new dance practices based on indigenous models; the research is an on-going project that seeks to ask the following questions;

1 Do you think that the case will address the missing link in the structure of contemporary Igbo dance theatre?

2 Will my interviews and observations help to elucidate the abstracted nature of Igbo dance theatre?

3 How relevant is Brad Haseman (2006) performative and Yvonne Hardt (2012) quoting repertory theories?

4 Does the Igbo dance theatre (archetype) have various sections? How are they connected? Is the dance development coherent and systematic?

5 I made use of interviews and studio practice in my research. To what extent is the movement style culturally informed or creatively choreographed?

6 How relevant is ethical consideration to this case?

\section{Further Readings}

Bryman, A. (2001) Social Research Methods. Oxford: Oxford University Press.

Carter, C. (2000) Improvisation in the Arts. The Journal of 
Aesthetics and Art Criticism Vol. 58, No. 2, (Spring, 2000), pp. 181-190.

Corbetta, P. (2003) Social Research Theory, Methods and Techniques. London: SAGE Publications.

Smith, H. and Dean, R. (2009) Introduction: Practice-Led Research, Research-led Practice-towards the Iterative Cyclic Wed. In: Hazel, S and Roger, D (eds.) Practice-Led Research, Research-led Practice in the Creative Arts. Edinburgh: Edinburgh University Press. pp. 1-40.

\section{References}

[1] Babbie, E. (2003) The Practice of Social Research. 10th edition. Califonia: Wadsworth Publishing Company.

[2] Bakare, O. (2006) The Contemporary Choreography in Nigeria: A Realistic Culture Preserver or a Harmful Distortionist? In: Yerima, A., Rasaki, B. and Udoka, A. (eds.) Critical Perspectives on Dance in Nigeria. Ibadan: Kraft Books Limited. pp. 64-75.

[3] Candy, L. (2006) Creativity \& Cognition Studios. In: Practice-based Research: A Guide [online]. Available from http://www.creativityandcognition.com. Accessed 15 November, 2012.

[4] Cohen, L., Manion, L., and Morrison K. (2000). Research Methods in Education. London: Routledge Falmer.

[5] Driscoll, D. (2011) Introduction to Primary Research: Observations, Surveys, and Interviews. In: Writing Spaces: Readings on Writing, Volume 2. Charles Lowe and Pavel Zemliansky (eds). New York: Hafner Publishing Co.

[6] Foddy, W. (1993) Constructing Questions for Interviews. Cambridge: Cambridge University Press.

[7] Fox, N. (1998) How to Use Observations in a Research Project. Sheffield: Trent Focus Group

[8] Frayling, C. (1997) Practice-based Doctorates in the Creative and Performing Arts and Design. Lichfield: UK Council for Graduate Education.

[9] Gray, D. E. (2004) Doing Research in the Real World. London: SAGE Publications.

[10] Hardt, Y. (2012) Engaging with the Past in Contemporary Dance. In: Manning, S and Ruprecht, L. (eds.) New German Dance Studies. Illinois: University of Illonois, pp. 217-231.
[11] Haseman, B. (2006) A Manifesto for Performative Research: Media International Australia Incorporating Culture and Policy, theme issue "Practice-led Research". Quarterly Journal of Media Research and Resources (no. 118):pp. 98106. Available from: http://eprints.qut.edu.au/3999/[Accessed 15 November, 2012].

[12] Holly, Anubhav, Patrick. (2002) Observation. $12^{\text {th }}$ November, 2002. Origins of Field Research [online]. Available from: http://www.public.asu.edu/ kroel/www500/Observation.pdf [Accessed 5th August, 2013].

[13] Kvale, S. (1996) Interviews. London: SAGE Publications.

[14] Magerko, B., \& Riedl, M. (2008). What Happens Next? Toward an Empirical Investigation of Improvisational Theatre. Presented at the 5th International Joint Workshop on Computational Creativity.

[15] Nadel, M. (ed) (1978) The process of Creating Dance. In: Myron, N and Constance, M. (eds) The Dance Experience: Reading in Dance Appreciation. New York: Universe Book. pp. 74-81.

[16] Ngo, David. (2010) Observation methods. 23 March, 2010. Human Resources. [online]. Available from: $\mathrm{http}: / / w w w . h u m a n r e s o u r c e s . h r v i n e t . c o m / o b s e r v a t i o n-$ methods/ [Accessed $5^{\text {th }}$ August, 2013].

[17] Portnoy, J. (1978) Is the Creative Process similar in Arts? In: Myron, N and Constance, M. (eds) The Dance Experience: Reading in Dance Appreciation. New York: Universe Book. pp. 157-175.

[18] Stone, S. (2007) Dance Improvisation Exercises for Choreographers and Dancers. Available from: http://voices.yahoo.com/dance-improvisation-exerciseschoreographers-and-563095.html [Accessed 15 November, 2012].

[19] Taylor. D. (2003) The Achieves and the Repertoire. Performing Cultural Memory in the Americas. Dunham: Duke University Press.

[20] Vincs, K. (2010) Rhizome/Myzone: A Case Study in StudioBased Dance Research. In: Estelle, B and Babara, B (eds). Practice as Research Approaches to Creative Arts Enquiry. London: I.B. Tauris \& Co Ltd. Pp. 99-112.

[21] Yerima, A. (2006) Nigeria Traditional Dancers: History and Practice. In: Yerima, A., Rasaki, B. and Udoka, A. (eds.) Critical Perspectives on Dance in Nigeria. Ibadan: Kraft Books Limited. pp. 17-44. 